NASA/TM—2007-214936

\title{
Flight Testing an Iced Business Jet for Flight Simulation Model Validation
}

Thomas P. Ratvasky

Glenn Research Center, Cleveland, Ohio

Billy P. Barnhart

Bihrle Applied Research, Inc., Jericho, New York

Sam Lee

ASRC Aerospace Corporation, Cleveland, Ohio

Jon Cooper

Cessna Aircraft Company, Wichita, Kansas 


\section{NASA STI Program . . . in Profile}

Since its founding, NASA has been dedicated to the advancement of aeronautics and space science. The NASA Scientific and Technical Information (STI) program plays a key part in helping NASA maintain this important role.

The NASA STI Program operates under the auspices of the Agency Chief Information Officer. It collects, organizes, provides for archiving, and disseminates NASA's STI. The NASA STI program provides access to the NASA Aeronautics and Space Database and its public interface, the NASA Technical Reports Server, thus providing one of the largest collections of aeronautical and space science STI in the world. Results are published in both non-NASA channels and by NASA in the NASA STI Report Series, which includes the following report types:

- TECHNICAL PUBLICATION. Reports of completed research or a major significant phase of research that present the results of NASA programs and include extensive data or theoretical analysis. Includes compilations of significant scientific and technical data and information deemed to be of continuing reference value. NASA counterpart of peer-reviewed formal professional papers but has less stringent limitations on manuscript length and extent of graphic presentations.

- TECHNICAL MEMORANDUM. Scientific and technical findings that are preliminary or of specialized interest, e.g., quick release reports, working papers, and bibliographies that contain minimal annotation. Does not contain extensive analysis.

- CONTRACTOR REPORT. Scientific and technical findings by NASA-sponsored contractors and grantees.
- CONFERENCE PUBLICATION. Collected papers from scientific and technical conferences, symposia, seminars, or other meetings sponsored or cosponsored by NASA.

- SPECIAL PUBLICATION. Scientific, technical, or historical information from NASA programs, projects, and missions, often concerned with subjects having substantial public interest.

- TECHNICAL TRANSLATION. Englishlanguage translations of foreign scientific and technical material pertinent to NASA's mission.

Specialized services also include creating custom thesauri, building customized databases, organizing and publishing research results.

For more information about the NASA STI program, see the following:

- Access the NASA STI program home page at http://www.sti.nasa.gov

- E-mail your question via the Internet to help@sti.nasa.gov

- Fax your question to the NASA STI Help Desk at 301-621-0134

- Telephone the NASA STI Help Desk at 301-621-0390

- Write to: NASA Center for AeroSpace Information (CASI) 7115 Standard Drive Hanover, MD 21076-1320 
NASA/TM-2007-214936

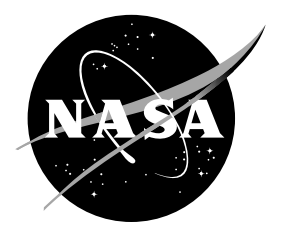

\section{Flight Testing an Iced Business Jet for Flight Simulation Model Validation}

Thomas P. Ratvasky

Glenn Research Center, Cleveland, Ohio

Billy P. Barnhart

Bihrle Applied Research, Inc., Jericho, New York

Sam Lee

ASRC Aerospace Corporation, Cleveland, Ohio

Jon Cooper

Cessna Aircraft Company, Wichita, Kansas

Prepared for the

45th Aerospace Sciences Meeting and Exhibit

sponsored by the American Institute of Aeronautics and Astronautics

Reno, Nevada, January 8-11, 2007

National Aeronautics and

Space Administration

Glenn Research Center

Cleveland, Ohio 44135 


\section{Acknowledgments}

The authors would like to thank the entire flight test support staff at Cessna for their outstanding efforts in conducting this flight test. Special thanks to Shane Kord and his crew for reconfiguring the airplane quickly and efficiently to keep the flight test moving forward. We also thank the NASA Aviation Safety and Security Program Office and Cessna Aircraft Company for sponsoring this effort.

Trade names and trademarks are used in this report for identification only. Their usage does not constitute an official endorsement, either expressed or implied, by the National Aeronautics and Space Administration.

Level of Review: This material has been technically reviewed by technical management.

Available from

NASA Center for Aerospace Information 7115 Standard Drive

Hanover, MD 21076-1320
National Technical Information Service 5285 Port Royal Road Springfield, VA 22161 


\title{
Flight Testing an Iced Business Jet for Flight Simulation Model Validation
}

\author{
Thomas P. Ratvasky \\ National Aeronautics and Space Administration \\ Glenn Research Center \\ Cleveland, Ohio 44135 \\ Billy P. Barnhart \\ Bihrle Applied Research, Inc. \\ Jericho, New York 11753 \\ Sam Lee \\ ASRC Aerospace Corporation \\ Cleveland, Ohio 44135 \\ Jon Cooper \\ Cessna Aircraft Company \\ Wichita, Kansas 67218
}

\begin{abstract}
A flight test of a business jet aircraft with various ice accretions was performed to obtain data to validate flight simulation models developed through wind tunnel tests. Three types of ice accretions were tested: pre-activation roughness, runback shapes that form downstream of the thermal wing ice protection system, and a wing ice protection system failure shape. The high fidelity flight simulation models of this business jet aircraft were validated using a software tool called "Overdrive.” Through comparisons of flight-extracted aerodynamic forces and moments to simulation-predicted forces and moments, the simulation models were successfully validated. Only minor adjustments in the simulation database were required to obtain adequate match, signifying the process used to develop the simulation models was successful. The simulation models were implemented in the NASA Ice Contamination Effects Flight Training Device (ICEFTD) to enable company pilots to evaluate flight characteristics of the simulation models. By and large, the pilots confirmed good similarities in the flight characteristics when compared to the real airplane. However, pilots noted pitch up tendencies at stall with the flaps extended that were not representative of the airplane and identified some differences in pilot forces. The elevator hinge moment model and implementation of the control forces on the ICEFTD were identified as a driver in the pitch ups and control force issues, and will be an area for future work.
\end{abstract}

\section{Nomenclature}

$\begin{array}{ll}\text { AOA } & \text { angle of attack } \\ \text { AvSSP } & \text { Aviation Safety and Security Program } \\ C_{L} & \text { aircraft lift coefficient } \\ C_{L, \text { max }} & \text { aircraft maximum lift coefficient } \\ \text { dF } & \text { flap deflection } \\ \text { ICEFTD } & \text { Ice Contamination Effects Flight Training Device } \\ \text { IPS } & \text { ice protection system } \\ \text { LWC } & \text { liquid water content } \\ \text { MAC } & \text { mean aerodynamic chord } \\ \text { OAT } & \text { outside air temperature } \\ \text { TLF } & \text { thrust for level flight }\end{array}$




$\begin{array}{ll}\mathrm{V} & \text { airspeed } \\ \mathrm{V}_{\mathrm{FE}} & \text { flap extension speed } \\ \mathrm{VMO} & \text { maximum operating speed } \\ \mathrm{Vs} & \text { stall speed } \\ \alpha & \text { aircraft angle of attack }\end{array}$

\section{Introduction}

In an effort to improve flight safety, NASA's Aviation Safety and Security Program (AvSSP) set out to develop and validate complete aircraft test methods and flight simulation models with emphasis on pilot training and aircraft icing certification testing. Specific objectives were to 1) develop piloted flight simulations to evaluate potentially risky flying qualities prior to development and certification flight tests with ice shapes and 2) develop piloted flight simulation models for operational training through higherfidelity flight training devices. To fulfill these objectives, NASA teamed with Cessna Aircraft Company and Bihrle Applied Research to develop and validate flight simulation models of a typical business jet that incorporates the effects of various forms of ice. Prior to this effort, NASA, Bihrle Applied Research and the Wichita State University developed and validated a flight simulation demonstrator for a turbo-prop commuter aircraft for pilot training (refs. 1 to 3 ).

The general methodology to develop the icing flight simulation models required static and dynamic wind tunnel testing of a subscale, complete aircraft model with and without ice shapes to develop a database of force and moment coefficients over a wide range of angles of attack, sideslip and control surface deflections. For the business jet simulation, a 1/12-scale complete aircraft model was used to develop the database for a no-ice baseline and three types of ice accretions. These were pre-activation roughness, runback shapes that form downstream of the thermal wing ice protection system, and a wing ice protection system failure shape. Because of the significant reduction in both the geometry and the Reynolds number, a series of wind tunnel tests was conducted on wing panel models prior to the 1/12-scale complete aircraft model testing. These wing panel model tests examined the scaling relationship between the full-scale aircraft and the subscale model with the three icing cases (ref. 4). From this scaling study, the subscale ice shape size, position, and roughness were determined for the complete aircraft testing. The 1/12-scale complete aircraft model was then tested on a rotary force-balance at the Bihrle Applied Research Large Amplitude Multi-Purpose Tunnel to develop the icing effects data base (ref. 5). Using this database, highfidelity flight simulation models for the baseline (no-ice) and three icing cases were developed using the Bihrle Applied Research simulation environment software called D-Six. A limited validation exercise was conducted on the baseline data using flight data provided by Cessna.

Additional flight test data with ice shapes were needed to validate the simulation models with the various forms of icing. Thus, a flight test program was conducted in Wichita, Kansas during September 2005 using a Cessna business jet to acquire the full-scale flight dynamics with the no-ice baseline and three icing cases. The intent of this report is to describe the flight test performed to gather full-scale icing effects data for simulation model validation, discuss and share results from the simulation validation process, and describe simulation implementation on a flight training device to note company pilot comments comparing actual flight characteristics to the simulation models as implemented on the NASA ICEFTD.

\section{Experimental Methods}

\section{A. Test Aircraft}

The test aircraft was a low-wing, T-tail twin pod-mounted turbo-fan light business jet which was modified for Cessna's development testing (fig. 1). The test aircraft was instrumented to measure accelerations, rates and attitudes, air data variables, control surface deflections, engine fan speeds and throttle positions, fuel quantities, and pilot forces. Data was recorded onboard and transmitted through 


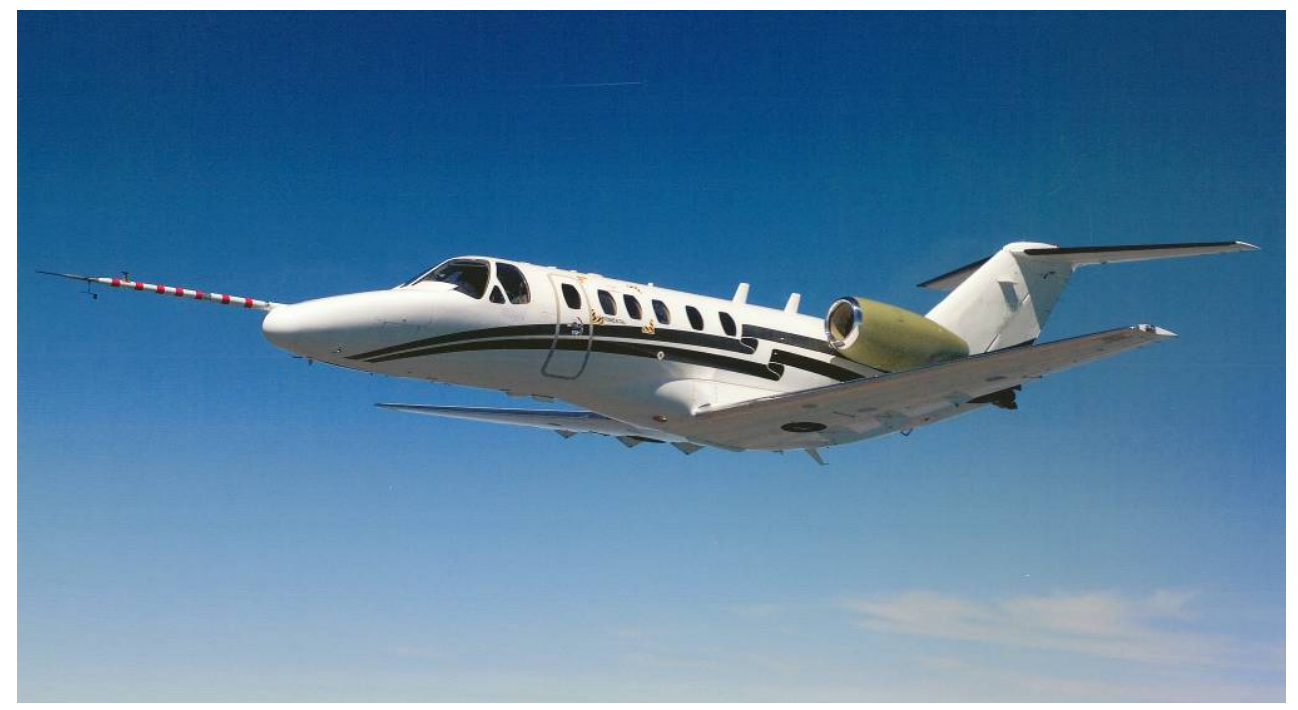

Figure 1.-Business jet test aircraft.

telemetry to a ground station for engineering test support personnel to monitor progress and provide guidance on the test maneuvers.

\section{B. Simulated Ice Accretions}

Three types of ice accretions were tested on the full-scale aircraft. These were 1) pre-activation roughness, 2) runback ice shapes that form downstream of wing thermal anti-ice system, and 3) wing ice protection system failure case. These are typical ice accretions considered in certification programs (ref. 6). The geometries of the pre-activation roughness and failure shape were obtained from LEWICE 1.6 calculations using the conditions in table 1 . The runback shapes were developed from flight test experience in natural and tanker icing encounters. All three shapes will be discussed in more detail below.

TABLE 1.-ICING CONDITIONS FOR PRE-ACTIVATION ROUGHNESS AND WING IPS FAILURE

\begin{tabular}{|l|c|c|c|c|c|c|}
\hline Ice shape & $\begin{array}{c}\text { Aircraft, } \\
\alpha(\mathrm{deg})\end{array}$ & $\begin{array}{c}\mathrm{V}, \\
\text { KCAS }\end{array}$ & $\begin{array}{c}\text { LWC, } \\
\mathrm{g} / \mathrm{m}^{3}\end{array}$ & $\begin{array}{c}\text { MVD, } \\
\mu \mathrm{m}\end{array}$ & $\begin{array}{c}\text { OAT, } \\
\mathrm{F}\end{array}$ & $\begin{array}{c}\text { Time, } \\
\mathrm{min}\end{array}$ \\
\hline $\begin{array}{l}\text { Pre-activation } \\
\text { roughness }\end{array}$ & 3.08 & 160 & 0.3 & 15 & -4 & 2 \\
\hline Wing IPS failure & 3.08 & 160 & 0.6 & 15 & 14 & 22.5 \\
\hline
\end{tabular}

\section{Pre-activation roughness configuration}

Pre-activation roughness represented a brief, initial icing encounter in which the ice protection systems were not active. Therefore, all flight surfaces (wing, vertical and horizontal tails) had a thin layer of ice roughness. The general position and locations of the pre-activation roughness was determined using LEWICE 1.6 and the conditions in table 1. LEWICE provided the geometric position of the icing extent for the wing and tail surfaces. Because the pre-activation shape did not have appreciable ice thickness, it was simulated using 40-grit sandpaper. Figure 2 shows the test aircraft with 40-grit sandpaper (blue areas) applied with double-sided tape on the leading edges of the wing and tail surfaces.

\section{Runback ice shape configuration}

The runback ice configuration represented an ice buildup after encountering an icing condition, such as very high liquid water content (LWC), which overwhelmed the wing thermal anti-icing system. In this scenario, some of the impacting liquid water would run aft of the ice protection system (IPS) and freeze on the upper and lower wing surfaces, while the leading edge remained free of ice. The other flight 


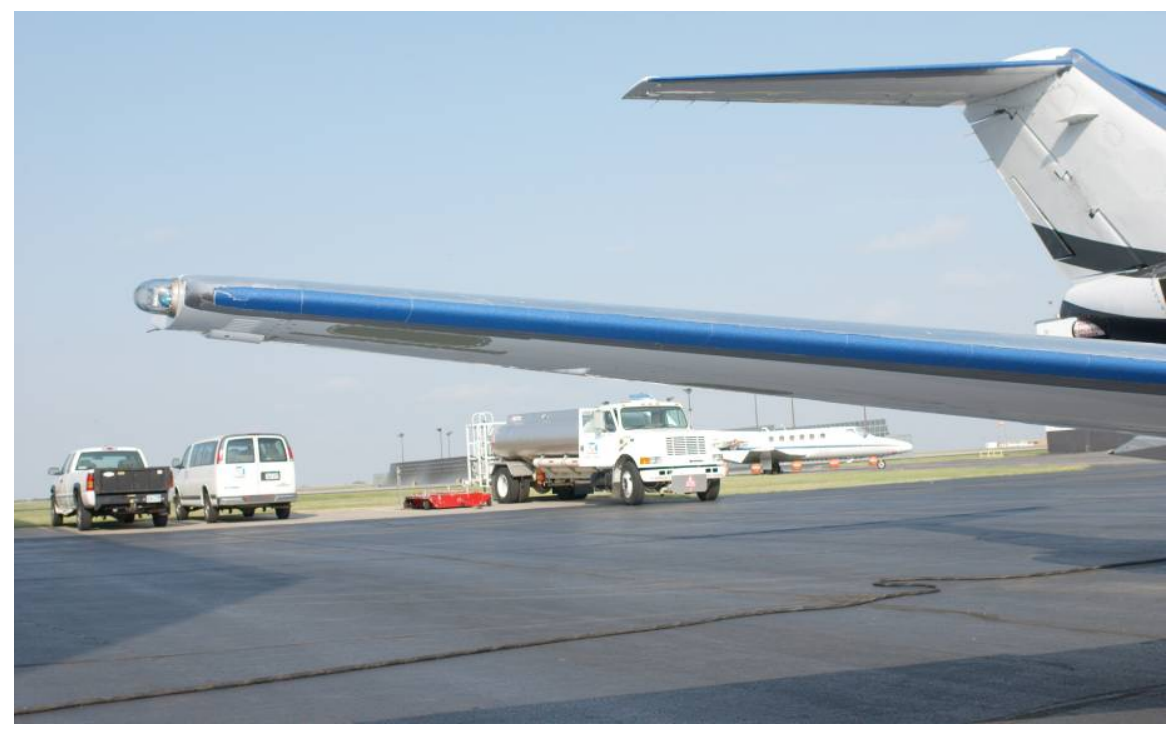

Figure 2.-Pre-activation roughness (40-grit sandpaper-blue) on wing and tails.

surfaces were assumed to have standard ice accretions, i.e., 45-min hold ice shapes on unprotected surfaces and inter-cycle ice on the horizontal tail.

With that scenario in mind, the aircraft configuration for runback ice consisted of an upper wing runback shape, a lower wing runback shape, 45-min LEWICE shapes on the unprotected parts of the wing and horizontal tail, and a 45-min LEWICE shape on the vertical tail. The pneumatic horizontal tail ice protection system was assumed to be operational, so 40-grit sandpaper was used on protected area of the horizontal tail to represent inter-cycle ice. The upper wing runback shape was represented by a solid hump approximately $4 \mathrm{in}$. chordwise and a maximum thickness of about 1/2 in. It was positioned on the upper wing just aft of the thermal ice protection system. It was made from a silicone-based material and mounted using adhesive and aluminum speed tape. Forty-grit roughness was applied to the shape to provide surface roughness. The lower wing runback shape was a forward-facing wedge shape approximately 2 in. chordwise and 11/2 in. in height. It was positioned on the lower wing just aft of the thermal ice protection system. It was made from foam and mounted using double-sided tape. Forty-grit roughness was applied as well. The ice shapes on the unprotected portions of the wing and tail were derived using LEWICE with the same conditions as the Failed IPS shown in table 1, but for a 45-min exposure. On this aircraft, the unprotected portions were the wing tips, the entire vertical stabilizer, the roots and tips of the horizontal stabilizer. All of the LEWICE-predicted ice shapes were fabricated from foam, mounted with aluminum speed tape and covered with 40-grit roughness.

Figure 3(a) and (b) show the right wing upper surface and lower surfaces of the runback configuration respectively. Note that the large shape on the wing tip is the 45-min LEWICE predicted shape on the unprotected wing tip.

\section{Wing IPS failure ice shape configuration}

The wing IPS failure configuration represented the ice buildup on the wing after an ice protection system failure [typically this is the amount of ice accumulated in $221 / 2 \mathrm{~min}$ (one-half of the 45-min hold condition) (ref. 6)]. The other flight surfaces were assumed to have standard ice accretions, i.e., 45-min hold ice shapes on the unprotected surfaces and inter-cycle ice on the horizontal tail.

Figure 4(a) and (b) show the right wing and horizontal tail for this configuration. The 22 1/2 -min LEWICE shape was mounted to the wing leading edge nearly full span. This LEWICE failure shape varied along the span due to changes in the wing geometry (chord length and twist) and local flow conditions. The large shape on the wing tip is the 45-min LEWICE shape on the unprotected part of the wing. In the background, the silver area on the vertical tail shows where the 45-min LEWICE shape was 


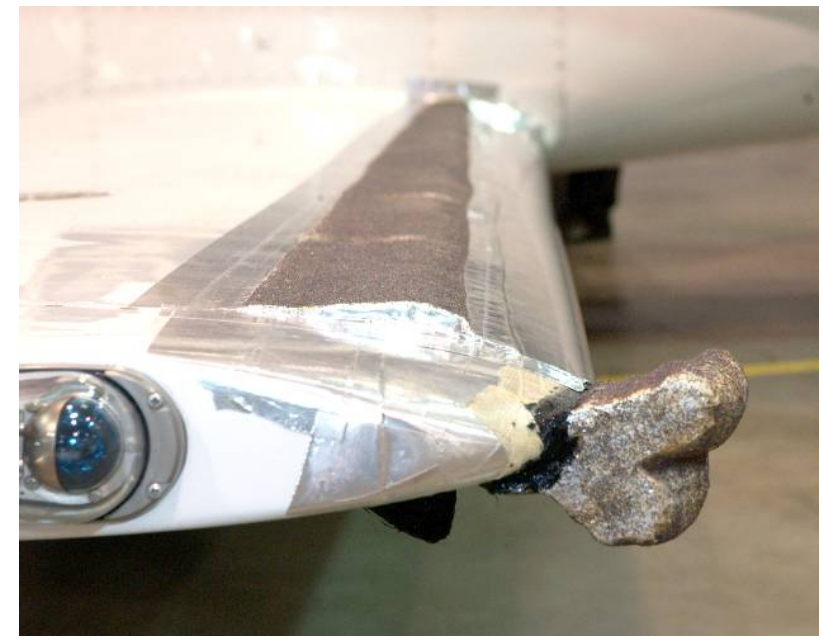

Figure 3(a).--Upper wing runback shape.

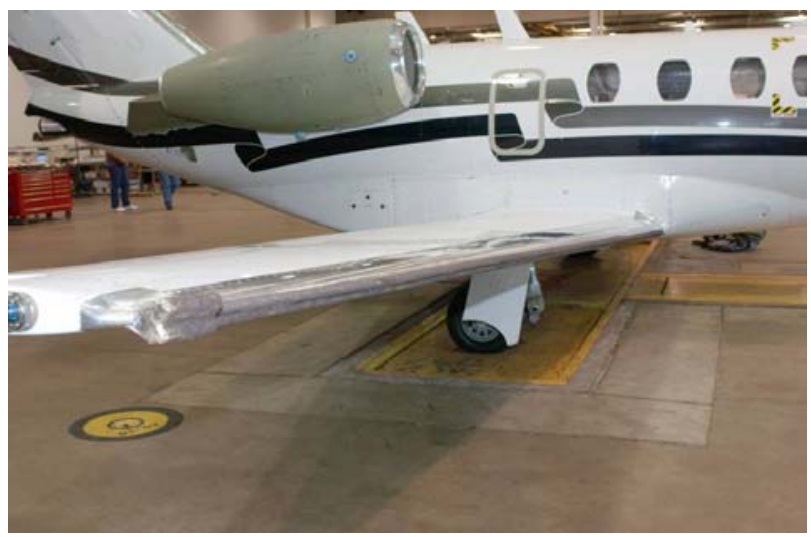

Figure 4(a).-Wing ice protection system failure case.

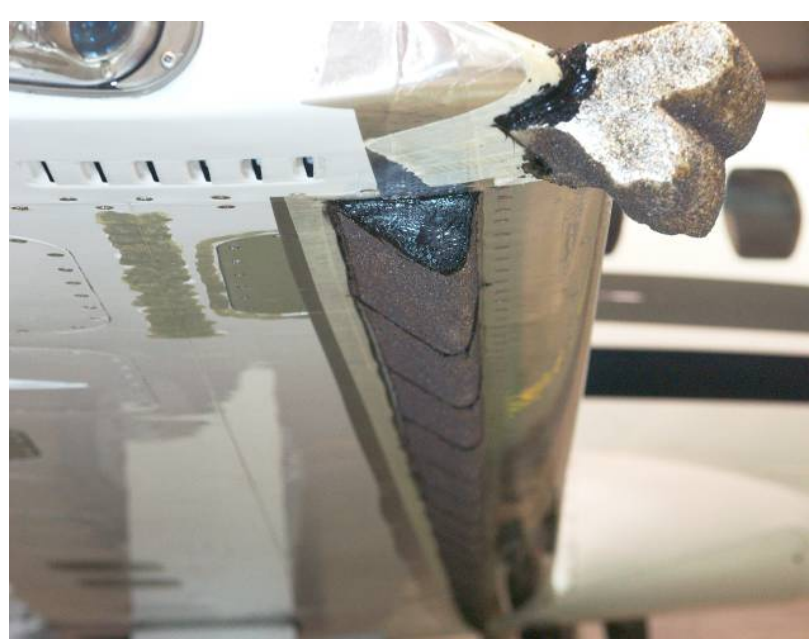

Figure 3(b).--Lower wing runback shape.

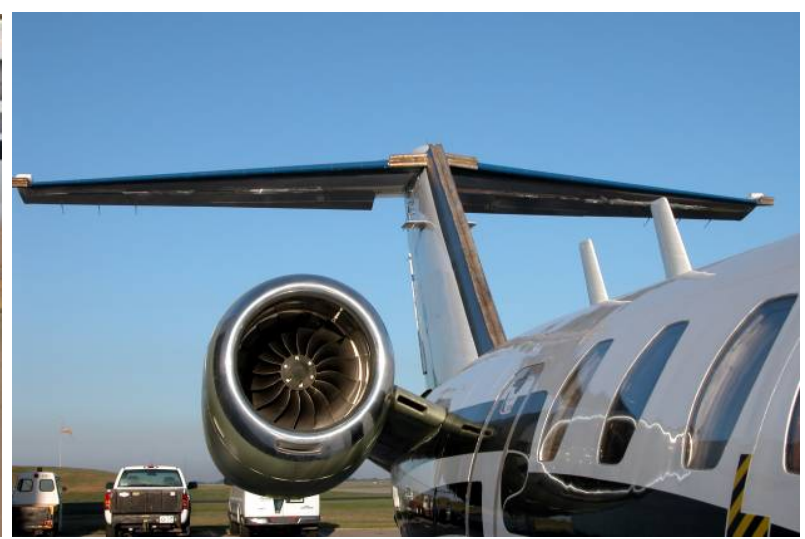

Figure 4(b).--Horizontal and vertical tail ice for the wing ice protection system failure case.

mounted. Figure 4(b) shows the right horizontal tail with the 45-min LEWICE shapes on the tip and root and the 40-grit sandpaper (blue) over the leading edge to represent inter-cycle ice. All of the LEWICE shapes were fabricated from foam and mounted using aluminum tape. Forty-grit roughness was applied to these ice shapes for surface roughness effects.

\section{Flight Test Maneuvers}

The test maneuvers were selected to acquire airplane response characteristics for validating the flight simulation models for the baseline and the three ice configurations described above. Particular interest was placed on the higher angle of attack (AOA) where icing effects were more apparent and on control doublets to verify control effectiveness. All maneuvers were conducted with a center of gravity near 25 percent mean aerodynamic chord (MAC) and initiated from trimmed steady-level conditions. All maneuvers were performed for $0^{\circ}$ flap, while a subset of the maneuvers were done at $15^{\circ}$ and $35^{\circ}$ flap. Table 2 in the appendix lists all the maneuvers and configurations tested. Below is a brief description of the maneuvers performed in this flight test.

\section{Idle-power stalls}

The aircraft was trimmed at 1.3 stall speed (Vs) for the specific flap and gear position required at idle power. Pilot recorded the trim event, and then applied longitudinal control to decelerate the aircraft at 1 knot per second. Pilot provided an event marker at the start of stick shaker and stall buffet and 
continued decelerating until either full aft column position was reached for 2 sec or aerodynamic stall break occurred. Stall recovery consisted of lowering the nose to reduce AOA and adding power. The purpose of this maneuver was to determine the aircraft $C_{L}$ curve as a function of angle of attack.

\section{Elevator, aileron and rudder doublets}

The aircraft was trimmed at $1.3,1.5$, and 1.7 Vs or flap extension speed $\left(\mathrm{V}_{\mathrm{FE}}\right)$ for the specific flap and gear position required at thrust for level flight. Pilot provided an event marker for the trim event, and then proceeded with a controls fixed elevator doublet. After the motion damped out, the pilot would check the trim, provide an event marker and perform an aileron doublet. After the motion damped out, the pilot would check the trim, provide an event marker and then perform a rudder doublet. The purpose of these maneuvers was to acquire data on control effectiveness and damping characteristics in longitudinal, lateral, and directional axes.

\section{Steady-heading sideslips}

The aircraft was trimmed at 1.3,1.5, and 1.7 Vs or $\mathrm{V}_{\mathrm{FE}}$ for the specific flap and gear position required at thrust for level flight. After noting the trim event, the pilot would perform steady a heading sideslip by slowly applying rudder while cross controlling with aileron input to maintain heading. The maneuver would end when full rudder deflection, $180 \mathrm{lb}$ pedal force, $15^{\circ}$ of sideslip, or buffet was attained. The pilot would slowly decrease rudder deflection and then repeat the process in the opposite direction. The purpose of this maneuver was to obtain data for lateral/directional forces, moments, and control effectiveness.

\section{Roll rate}

The aircraft was trimmed at $1.3,1.5$, and 1.7 Vs or $\mathrm{V}_{\mathrm{FE}}$ for the specific flap and gear position required at thrust for level flight. After noting the trim event, the pilot established a steady turn to the left with a $30^{\circ}$ bank angle. Once the left turn was established, the pilot used 1/3 aileron deflection to the right to roll the airplane to $30^{\circ}$ right bank angle. The steady right turn was established, and then the pilot input a $2 / 3$ aileron deflection to the left to roll the airplane to $30^{\circ}$ left bank angle. Again the steady left turn was established, and then the pilot input a full aileron deflection to the right to roll the airplane to $30^{\circ}$ right bank angle. The purpose of this maneuver was to obtain data for lateral damping and control effectiveness.

\section{Maneuvering characteristics}

The aircraft was trimmed at 1.3, 1.5, and 1.7 Vs or $\mathrm{V}_{\mathrm{FE}}$ for the specific flap and gear position required at thrust for level flight. After noting the trim event, the pilot would perform a wind up turn by steadily rolling and increasing back pressure on the column until $2 \mathrm{G}$ or buffet was attained. After the wind up turn, the aircraft was returned to straight and level flight, and a series of $2 \mathrm{G}$ pull-ups and push-over maneuvers to 0.5 and $0 \mathrm{G}$ were conducted. Pilots commented on the controllability of the aircraft. The purpose of these maneuvers was to obtain load factor, elevator, and column force data during each test condition.

\section{Thrust transients}

The aircraft was trimmed at $1.3 \mathrm{Vs}$ for the specific flap and gear position required at thrust for level flight. After noting the trim event, the pilot rapidly advanced the throttles to maximum continuous thrust. The pilot maintained altitude while the aircraft accelerated by pushing the column forward. The maneuver was completed when maximum operating speed (VMO) or $\mathrm{V}_{\mathrm{FE}}$ was reached. The purpose of this maneuver was to identify thrust effects on trim control positions and pilot forces.

\section{Flap extension}

The aircraft was trimmed at $1.3 \mathrm{Vs}$ or $\mathrm{V}_{\mathrm{FE}}$ for the specific flap and gear position required at thrust for level flight. Pilot provided an event marker for trim and then extended the flaps while maintaining initial 
trimmed airspeed by adjusting aircraft attitude. Pilot commented on the control forces needed to maintain airspeed as the flaps extended. The purpose of this maneuver was to identify flap effects on changes in trim control positions and pilot forces.

\section{Flight Tests}

The flight tests were conducted in a build up of increased performance and control degradation. The initial flight was the no-ice baseline and the full test matrix in table 2 was accomplished in one flight. The next configuration was the Pre-activation Roughness. Since this configuration had not been flown in any previous tests, a series of buildup flights was required. In the first pre-activation flight, the 40-grit sandpaper was attached to the horizontal and vertical stabilizers and the inboard 1/3 span of the wing. After successfully qualifying this intermediate configuration, 40-grit sandpaper was attached to the next $1 / 3$ span of the wing and was flight qualified. The last $1 / 3$ span was then covered and the full test matrix was accomplished for the pre-activation configuration in 2 flights. The next configuration flown was the runback ice, which had been flown in a previous program, so no buildup was required. All sandpaper was removed except for the horizontal tail ice protected area. The 45-min LEWICE shapes were attached to the unprotected leading edges, and the runback shapes were attached to the upper and lower surfaces of the wing. The full test matrix was accomplished in one flight. The last configuration was the Wing IPS Failure case. The Runback shapes were removed and a buildup of the Failure ice shape in 1/3 span increments (similar to the Roughness) took place to qualify this configuration. On the third flight, the full test matrix was conducted for the Wing IPS Failure configuration.

The entire flight test was conducted in 11 flights (including qualification flights) in a total of 18.3 flight hours. From those flights, a total of 200 test maneuvers were performed.

\section{E. Flight Simulator Sessions}

Prior to the flight test program, the preliminary flight simulation models of this business jet were implemented on NASA's ICEFTD. The ICEFTD is a portable flight simulator that was developed as a concept demonstrator for building icing effects into flight simulation models for pilot training (refs. 2 and 7). The business jet models had only limited validation for the no-ice case and the three iced cases were essentially unverified. The ICEFTD was shipped to Wichita, and during the course of the flight test program, company pilots flew various maneuvers in the ICEFTD with the various ice formations (fig. 5(a)). Pilots provided verbal comments comparing the simulator to the flight.

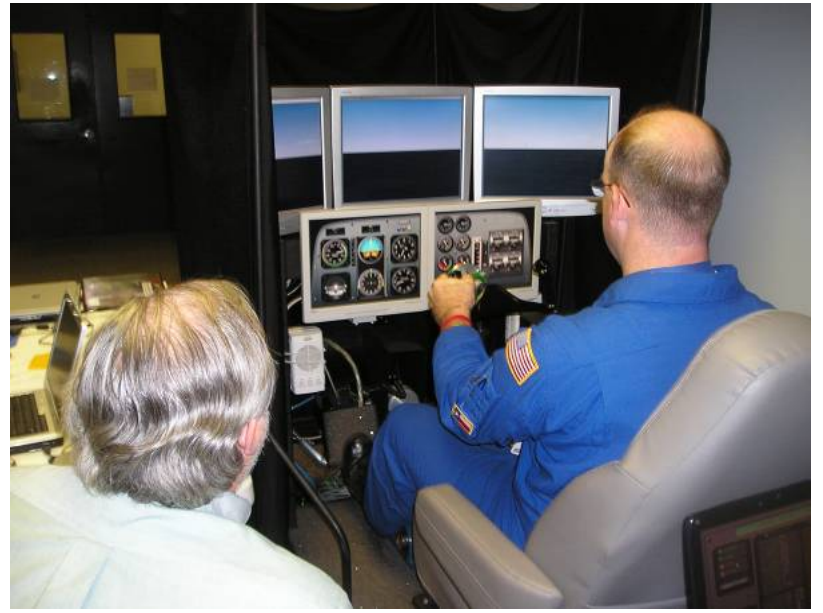

Figure 5(a).-ICEFTD session during flight test.

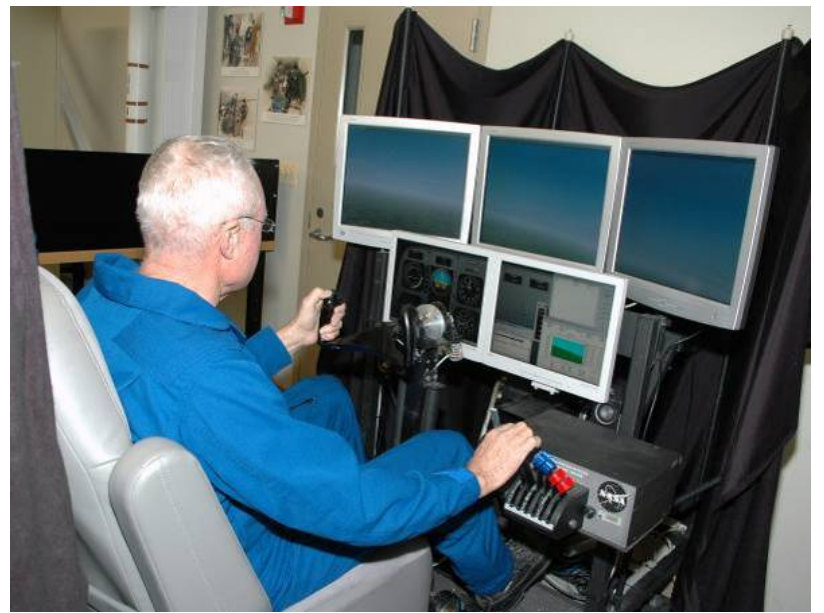

Figure 5(b).--ICEFTD session after model update. 
After the flight test program, the flight simulation models were updated and re-implemented in the ICEFTD. Company pilots and engineers flew a series of maneuvers in the ICEFTD with the updated simulation models and again provided verbal comments comparing the simulator to flight (fig. 5(b)). These comments will be discussed in the next section.

\section{Results and Discussion}

\section{A. Simulation Model Validation}

Flight test data were parsed into discrete data files for each maneuver and subsequently analyzed using the "Overdrive" tool in the Bihrle Applied Research's D-Six simulation software (ref. 8) to validate the simulation models. "Overdrive" enabled the validation of the simulation aerodynamic database against flight-extracted data using the process illustrated in figure 6. At each time slice, extraction of aerodynamic moment coefficients from the flight-recorded time history occurred as shown on the right side of figure 6 . Angular rates were numerically differentiated to obtain the angular acceleration of the vehicle. After the removal of the inertial effects, the remainder was nondimensionalized to calculate the aerodynamic force and moment coefficients experienced during flight. Also, at each time step, flightrecorded states, such as angle of attack, angle of sideslip, control surface positions, etc., were used to drive the aerodynamic model. Each aerodynamic model element (i.e., pitching moment due to elevator, etc.) was stored and summed as prescribed in the aerodynamic model. By over-plotting the model predicted coefficients with the flight-extracted total coefficients, differences were easily identified. When discrepancies were found, the simulation database was refined. The data would be rechecked with Overdrive to verify the refinement.

\section{General flight dynamics validation}

The validation effort showed that, in general, the original business jet simulation models that were developed from the wind tunnel data correlated well with the flight records. The validation effort resulted in only minor adjustments to the simulation models. The general flight characteristics for low to mid-level

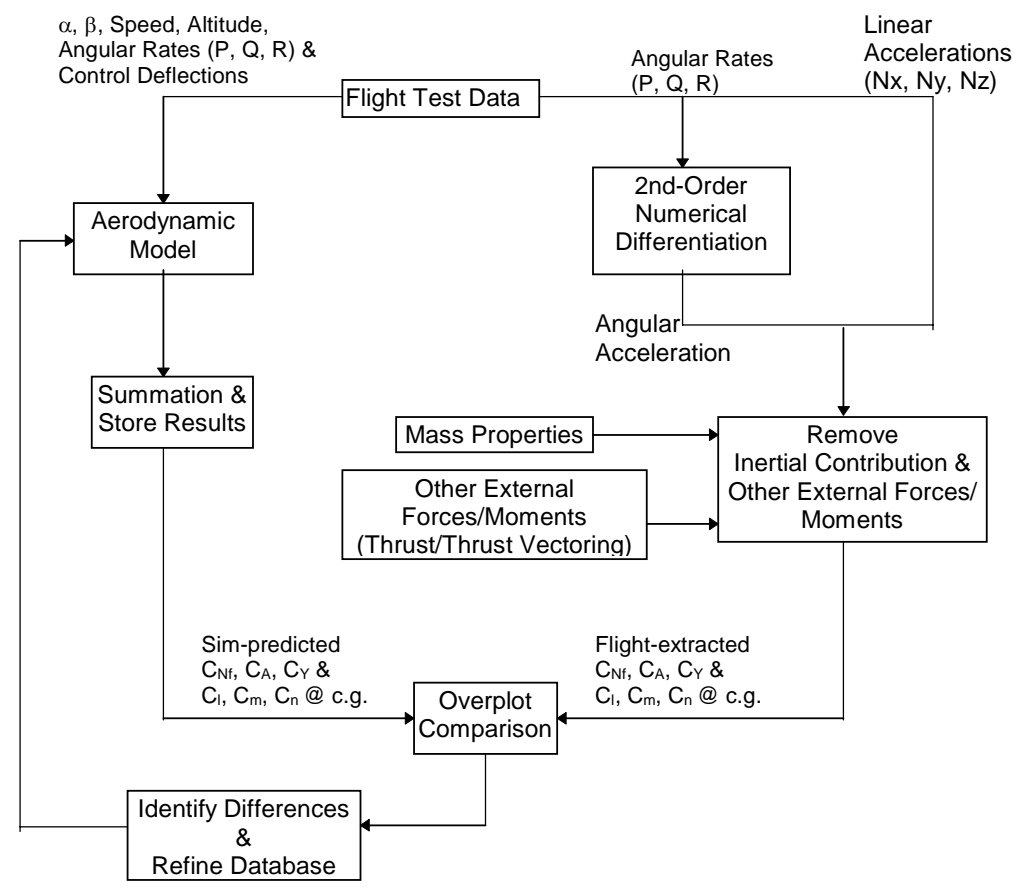

Figure 6.-Overdrive block diagram. 
angles of attack were exceptionally well correlated. To verify general flight characteristics, maneuvers such as the steady heading sideslip and control doublets were examined. Examples of the "Overdrive" results for the steady heading sideslip and elevator, aileron and rudder control doublets are shown in figures 7 and 8 respectively.

Figure 7 shows the Overdrive results from a steady heading sideslip maneuver. The time histories in the top 3 plots show the flight inputs while the 4th plot shows the simulation-predicted (blue) and flight derived (red) side force coefficient (CY) for this maneuver. The 5th plot displays the components of the simulation-prediction of CY. Note the close match between the simulation results and the flight derived terms as the sideslip (betad) varies over the range of $-15^{\circ}$ to $15^{\circ}$. This is an example of a good match for lateral directional characteristics.

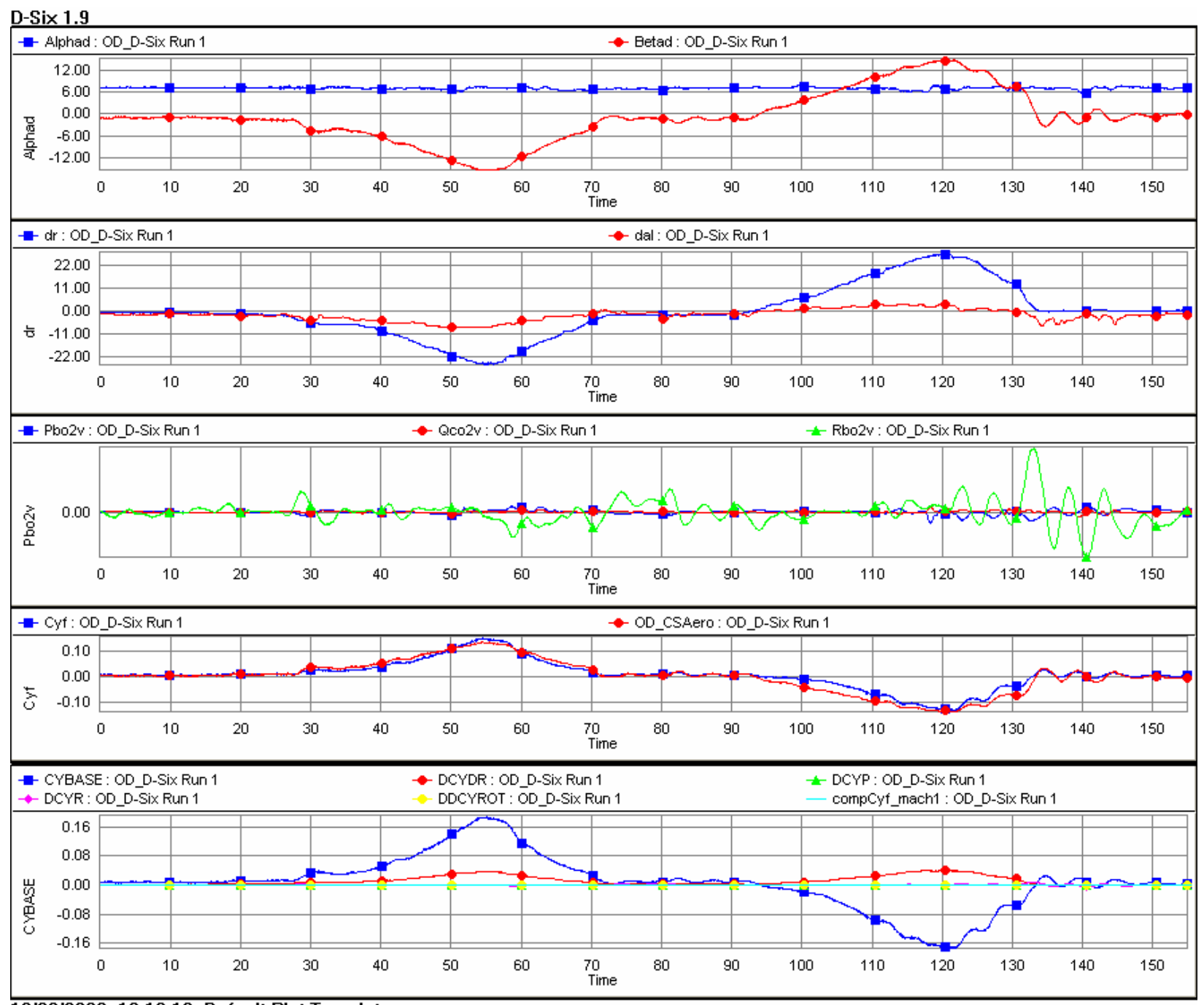

10/02/2006 18:13:12 Default Plot Template

Figure 7.- Steady heading sideslip overdrive result. 
D-Six 1.9
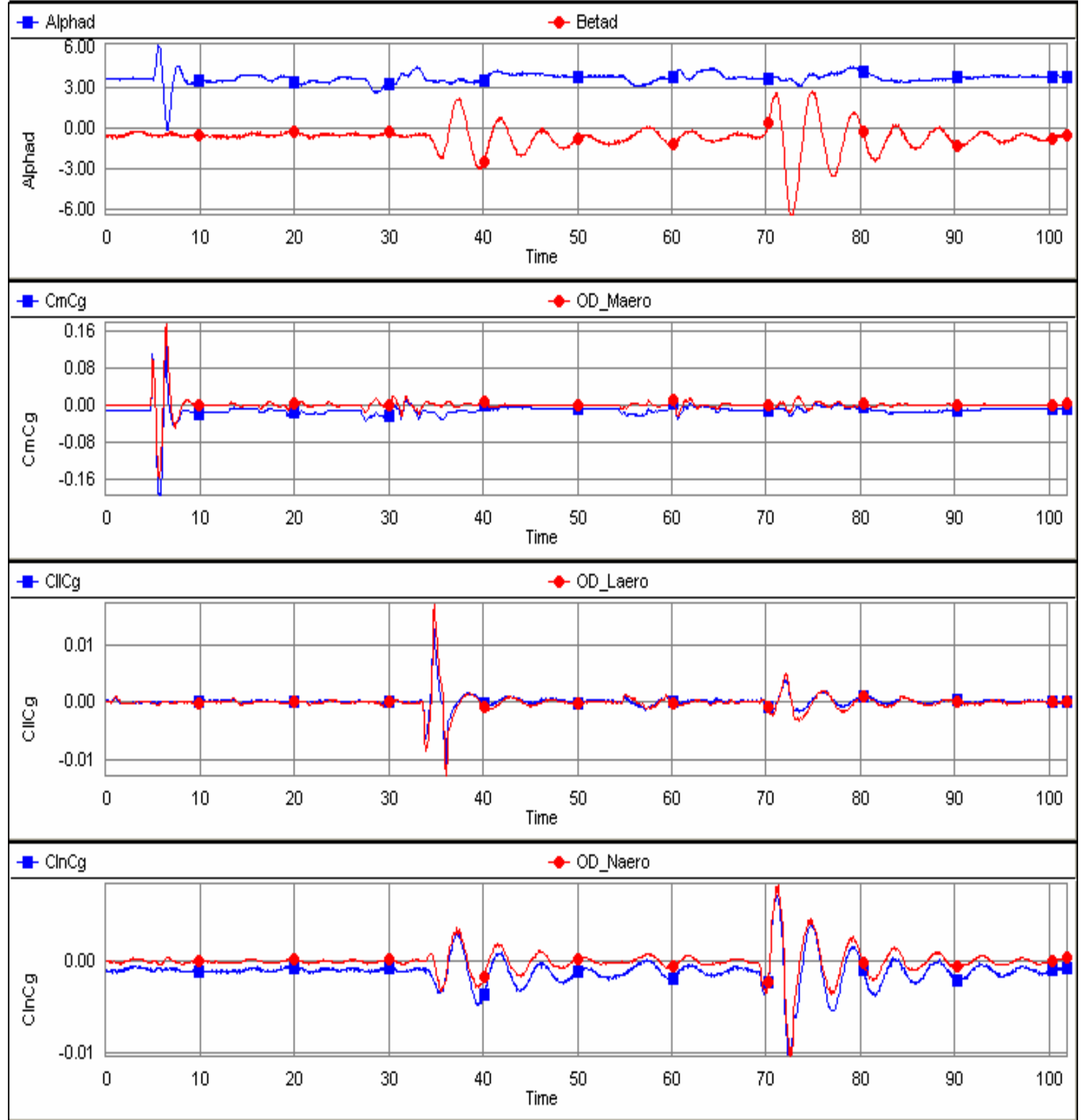

\section{0/03/2006 15:05:47 Default Plot Template}

Figure 8.-Control doublets overdrive result.

Figure 8 shows the Overdrive results from a series of control doublets. The first input was an elevator doublet, the second was an aileron doublet, and the third was a rudder doublet. The first time histories show the angle of attack and sideslip from flight. The remaining three plots show the pitching moment, rolling moment and yawing moment time histories. The red traces are the flight derived terms while the blue traces are the simulation predicted moments. Clearly the simulation models accurately represent the flight records for these maneuvers. This suggests that the simulation models accurately represent control effectiveness and long and short period flight dynamics. 


\section{Icing Effects Model Validation}

The primary objective of the flight test program was to acquire data for validating the icing effects simulation models for the various ice accretions. Prior to this flight program, these simulation models were unverified. Critical points to accurately simulate were the speeds and angles of attack where stall occurred and the aircraft motion throughout the stall and recovery. The icing effects are clearly seen in the lift and pitching moment coefficients at higher angles of attack where flow separation and ultimately stall occurred. Figure 9 shows the lift curves for the no-ice and 3 iced cases derived from idle-power stall maneuvers to provide an overall sense of the effect of these ice accretions on the aircraft performance.

The No-Ice lift curve provides a baseline reference. The lift plateaus at $C_{L \text { max }}$ with no sharp break at the maximum angle of attack. With the Pre-activation Roughness, the $C_{L \max }$ and stall angle of attack are nearly the same as the No-Ice baseline, but has a rather sharp stall break, and no plateau as was observed in the baseline. The larger ice accretions (Runback and Failure cases) had a more substantial degradation on lift performance. In both cases, the stall angle of attack was reduced by about $3^{\circ}$ and the $C_{L \max }$ was reduced by about 0.2 . The character of the lift curves also resembled the No-Ice baseline in the flat plateau region prior to maximum angle of attack. Similar changes in stall characteristics due to the ice accretions were measured for the flaps extended configurations.

To validate the icing effect in the simulation models, the Overdrive tool was used on the stall maneuvers in the same way as in the steady heading sideslip and the control doublets. Figure 10 shows the Overdrive result for the No-Ice, flaps up idle-power stall maneuver. The second plot in this figure displays the simulation-predicted lift coefficient as a function of time as well as the flight-extracted lift coefficient. A good match is observed throughout the maneuver even at high angles of attack and at stall recovery. Likewise, Overdrive was used on the stall maneuvers for each ice configuration. Figure 11 shows the results for the Pre-Activation Roughness, flaps up configuration. The second plot shows a good match between the simulation-predicted and flight-extracted lift coefficients throughout the maneuver including stall recovery. Lastly, figure 12 shows the results for the Failed IPS Ice, flaps up configuration. Except for a small offset (0.02) in $C_{L}$ at the beginning of the maneuver, the simulation-predicted lift coefficient matched the flight-extracted lift coefficient very well, particularly at stall and what appears to be a secondary stall that occurred during the recovery.

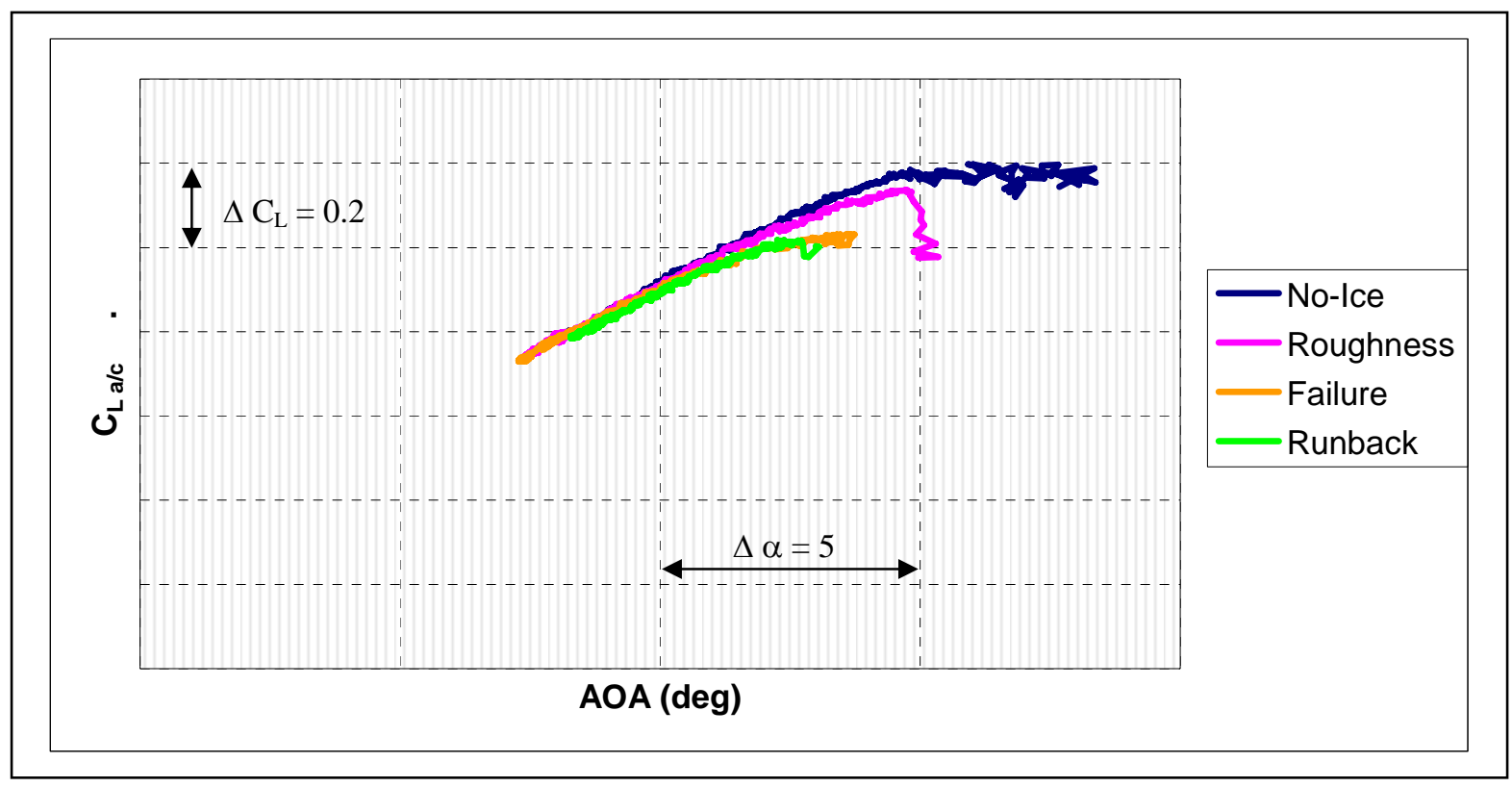

Figure 9.-Flight derived lift curves for various ice accretions $(\mathrm{dF}=0)$. 


\section{B. Simulation Model Implementation and Evaluation on the ICEFTD}

Using the Overdrive tool, all the stall maneuvers for each flap setting and ice configuration were similarly validated. When discrepancies were found between the simulation-predicted and the flightextracted force and moment coefficients, the deficiencies in the model were identified and corrected. Generally, the models required only minor adjustments. The model coefficient that required the most work was the pitching moment near stall for the flaps down cases. The original simulation model tended to have a pitch up tendency at stall. This was corrected by extending the nose-down pitching moment curve to a slightly higher angle of attack for these cases.

The business jet simulation models were implemented on the ICEFTD so that company test pilots could experience the change in flight characteristics prior to the flight with each ice shape. Two company pilots flew the ICEFTD with each ice accretion configuration and provided comments based on their experience with the aircraft. The comments were favorable on the general flight characteristics. The longitudinal short period response was well damped, and the roll response was a good match. The primary discrepancy was with a pitch up that occurred during stall maneuvers with the flaps deflected to $15^{\circ}$ and $35^{\circ}$. Another discrepancy was with column forces. The ICEFTD provided control feedback through the column using a stick-loader system. The column forces were modeled using elevator hinge moment data in D-Six which provided commands to the stick-loader based on the flight conditions and pilot input. The stick forces were adjusted during this session, and pilots felt it resolved the issue in general. However, the forces were not representative at stall. The pilots expected a rather large pull force required during stall, but experienced push forces required to maintain pitch attitude. The pilot forces at the stall point appeared to drive the pitch up that was observed.

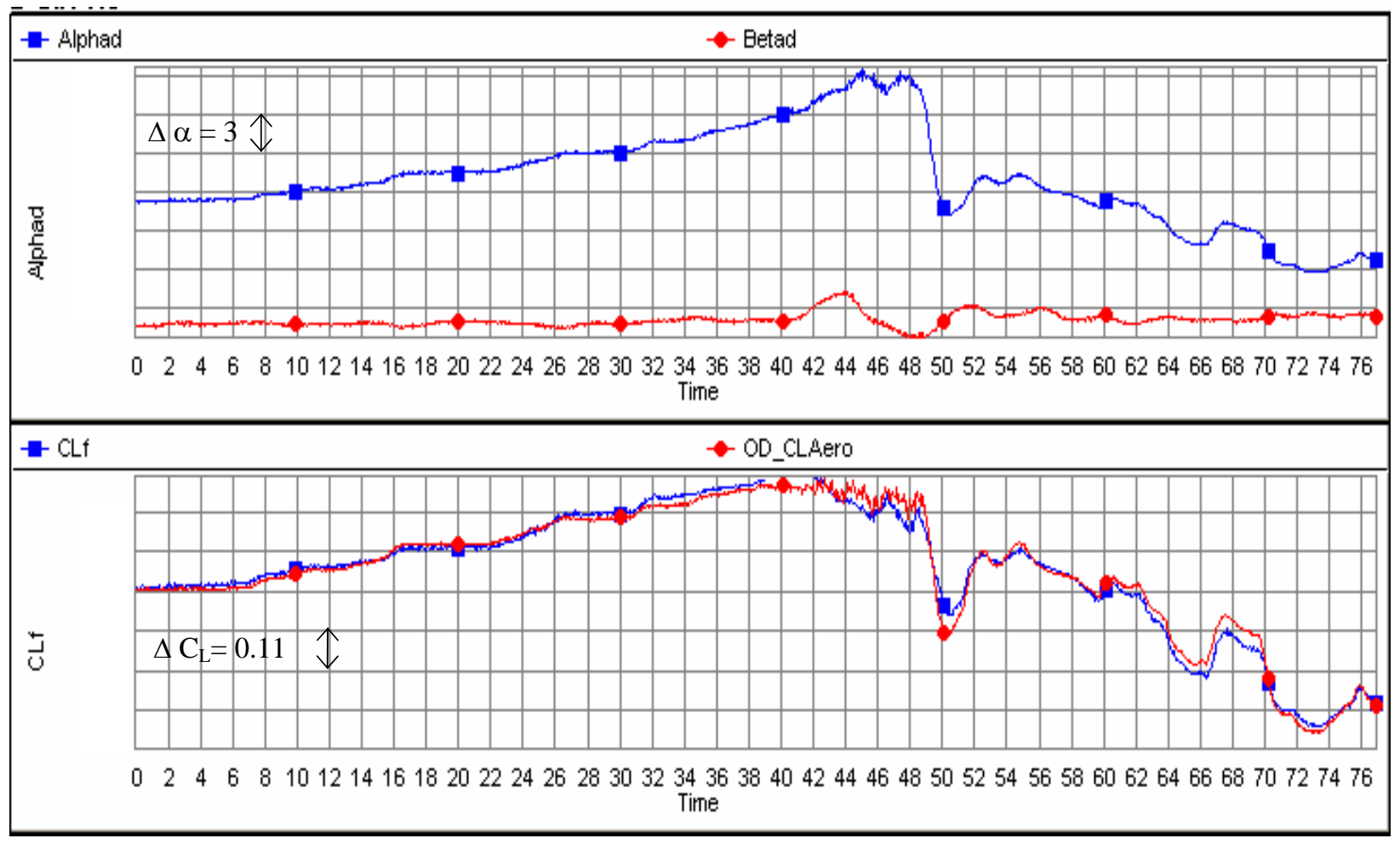

Figure 10.-Idle-power stall overdrive result (no-ice, $\mathrm{dF}=0^{\circ}$ ). 


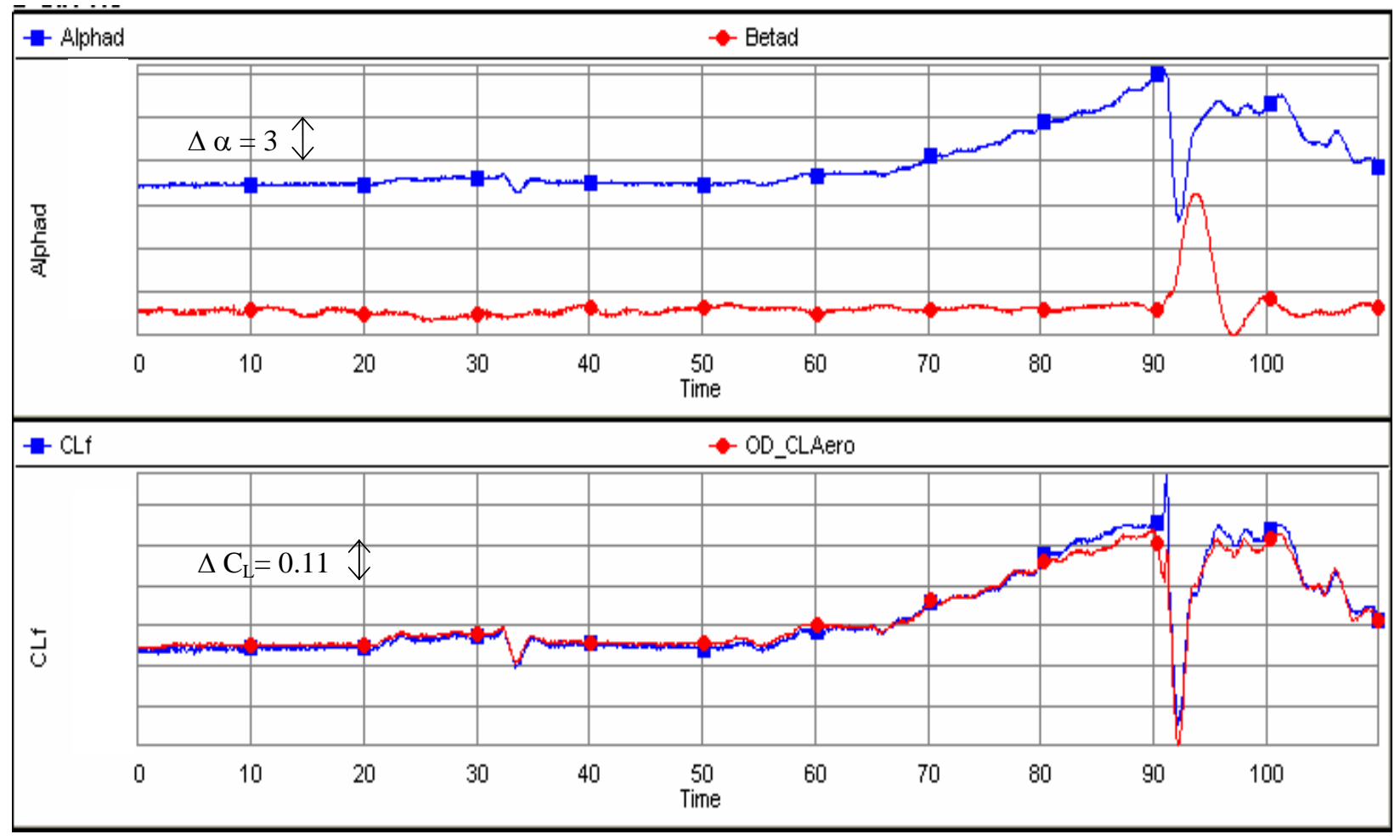

Figure 11.-Idle-power stall overdrive (roughness, $\mathrm{dF}=0^{\circ}$ ).

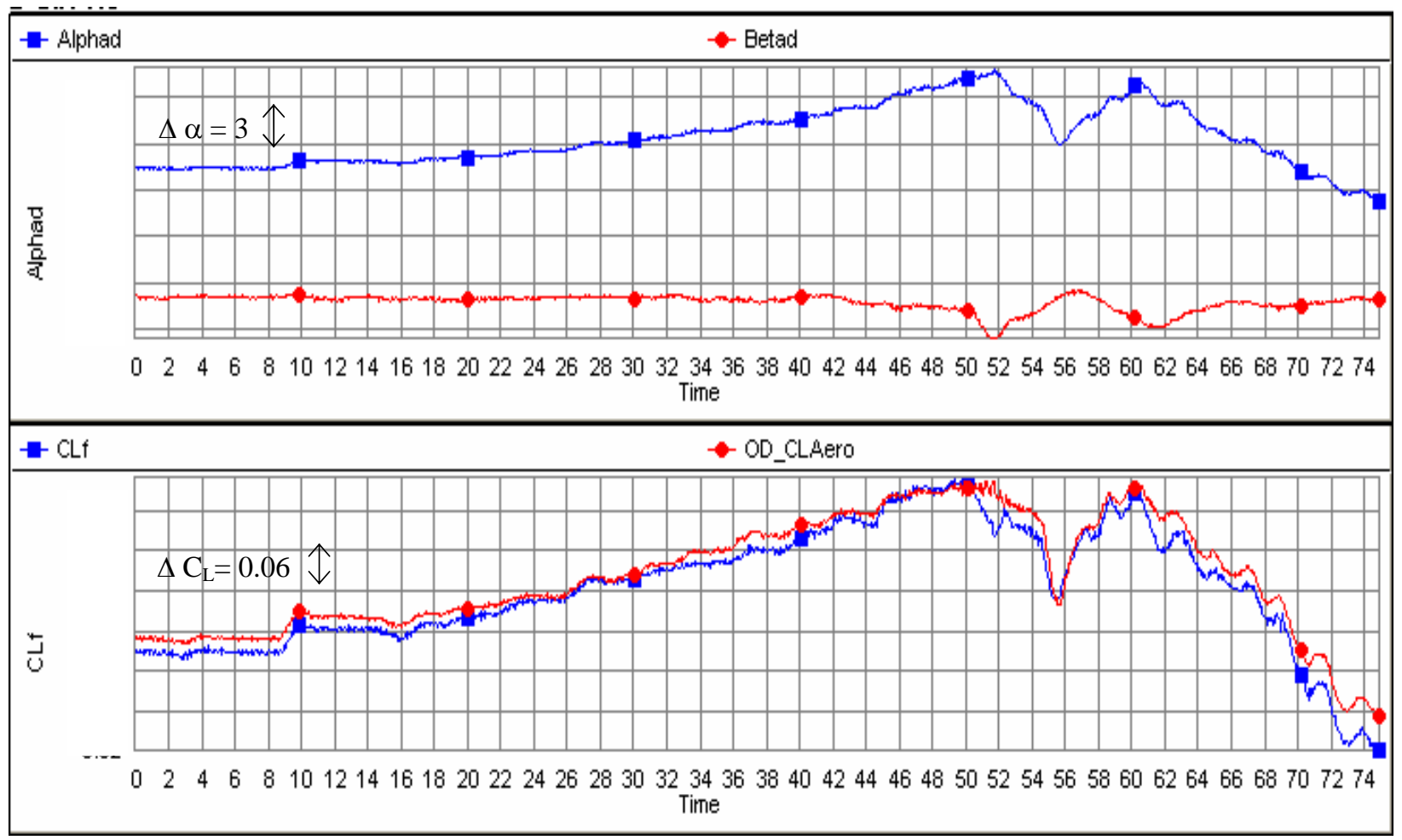

Figure 12.-Idle-power stall overdrive (failed IPS ice, $\mathrm{dF}=0^{\circ}$ ) 
After the flight test, the simulation models were validated using the Overdrive tool as described above. The updated simulation models were re-implemented onto the ICEFTD, and the company pilots and engineers were invited to evaluate them. A test matrix similar to the flight test was developed, and each pilot flew each iced configuration at three flap settings to evaluate the general flight and stall characteristics. In general, both pilots considered the simulation to be representative for the flaps-up cases. Longitudinal and lateral/directional responses were similar to the aircraft, and stall characteristics were accurately represented for the No-Ice and various iced configurations. With flaps deflected, however, the pilots identified unrealistic pitch up tendencies at stall.

Through this evaluation session, the team identified the elevator hinge moment model as a potential driver for these pitch up tendencies. At the angles of attack near stall, the ICEFTD control column forces tended to lighten and reverse. If unchecked by the pilot, the column movement would drive the elevator in a nose up manner and increase the angle of attack to very high (greater than $30^{\circ}$ ) values. In flight, the pull forces in the column increased as the elevator deflected trailing edge up, so that at stall, the pilot only needed to reduce the pull force to allow the column to move forward. In the ICEFTD, the pilots needed to push forward on the column to break the stall before very high angles of attack were attained. The elevator hinge moment model used in the ICEFTD was developed from low-speed wind tunnel test data provided by the company. This wind tunnel test data accounted for changes in elevator hinge moment due to flap deflection, but did not account for changes due to ice accretions. Additionally, the validation process using Overdrive focused on the verifying the aerodynamic forces and moments, not the control hinge moments. Therefore the hinge moment model was essentially unverified during these evaluation sessions. As a result of these evaluations, an additional validation effort focusing on the elevator hinge moment is warranted.

\section{Conclusion}

A business jet aircraft was flight tested to measure the aerodynamic effects that three types of ice accretion had on the flight characteristics. The flight test data were used to validate flight simulation models that were developed through wind tunnel tests of a sub-scale complete aircraft model with test conditions representing the same three ice accretions. The validation process utilized a tool called Overdrive that compared flight-extracted aerodynamic forces and moments to simulation-predicted forces and moments. If discrepancies were discovered in these comparisons, the simulation engineer isolated the source of the discrepancy and adjusted the simulation model database to correct the model. The simulation models were implemented on a fixed based flight training device called the ICEFTD to enable pilot evaluations of the simulation models.

The flight simulation models were successfully validated using the data collected through this flight test program. Validation was demonstrated through the Overdrive process which showed good match between flight-extracted forces and moments and simulation-derived forces and moments for the baseline and all three iced configurations. The adjustments to the simulation model database to achieve the good match were considered minor. Therefore the process to develop the icing effects simulation database was considered successful.

Implementing these simulation models for pilot evaluation on the ICEFTD revealed an essential component in the simulation that had not been verified initially. The pilot-in-the-loop evaluations identified pitch up tendencies at stall with the flaps extended. The likely driver for these pitch ups was the elevator hinge moment model. Elevator hinge moments were modeled and implemented in the ICEFTD, but the model and the implementation of the model in the ICEFTD had not been verified with the same rigor as the aerodynamic forces and moments. The significance to this finding is that although the aerodynamic models may be accurate, a pilot may regard the simulation as inaccurate because of the effect that control forces have on the simulation. As a result of this finding, an additional effort will be made to verify the hinge-moment model and control force implementation on the ICEFTD. 


\section{Appendix}

TABLE 2.-FLIGHT TEST MANEUVERS AND CONFIGURATION MATRIX

\begin{tabular}{|c|c|c|c|c|c|c|c|}
\hline Cond & Procedure & WT & CG & FL/GR & Speed & Alt & Thrust \\
\hline 1 & Flap extension & Opt & $25 \%$ & 0/up & $1.3 \mathrm{~V}_{\mathrm{s}}$ & 10 to $15 \mathrm{k}$ & TLF \\
\hline 2 & Flap extension & Opt & $25 \%$ & $15 / \mathrm{dn}$ & $1.3 \mathrm{~V}_{\mathrm{s}}$ & 10 to $15 \mathrm{k}$ & TLF \\
\hline 3 & Flap extension & Opt & $25 \%$ & 0/up & 200 & 10 to $15 \mathrm{k}$ & TLF \\
\hline 4 & Flap extension & Opt & $25 \%$ & $15 / \mathrm{dn}$ & 161 & 10 to $15 \mathrm{k}$ & TLF \\
\hline 5 & Roll rate & Ont & $25 \%$ & 0 מנונ & $13 \mathrm{~V}$ & 10 to $15 \mathrm{k}$ & TIF \\
\hline 6 & Roll rate & Opt & $25 \%$ & 0/up & $1.5 \mathrm{~V}_{\mathrm{s}}$ & 10 to $15 \mathrm{k}$ & TLF \\
\hline 7 & Roll rate & Opt & $25 \%$ & 0/up & $1.7 \mathrm{~V}_{\mathrm{s}}$ & 10 to $15 \mathrm{k}$ & TLF \\
\hline 8 & Roll rate & Opt & $25 \%$ & 15/up & $1.3 \mathrm{~V}_{\mathrm{s}}$ & 10 to $15 \mathrm{k}$ & TLF \\
\hline 9 & Roll rate & Opt & $25 \%$ & 15/up & $1.5 \mathrm{~V}_{\mathrm{s}}$ & 10 to $15 \mathrm{k}$ & TLF \\
\hline 10 & Roll rate & Opt & $25 \%$ & 15/up & $\mathrm{V}_{\mathrm{FE}}$ & 10 to $15 \mathrm{k}$ & TLF \\
\hline 11 & Roll rate & Opt & $25 \%$ & $35 / \mathrm{dn}$ & $1.3 \mathrm{~V}_{\mathrm{s}}$ & 10 to $15 \mathrm{k}$ & TLF \\
\hline 12 & Roll rate & Opt & $25 \%$ & $35 / \mathrm{dn}$ & $1.5 \mathrm{~V}_{\mathrm{s}}$ & 10 to $15 \mathrm{k}$ & TLF \\
\hline 13 & Roll rate & Opt & $25 \%$ & $35 / \mathrm{dn}$ & $\mathrm{V}_{\mathrm{FE}}$ & 10 to $15 \mathrm{k}$ & TLF \\
\hline 14 & Thrust transients & Ont & $25 \%$ & $0 /$ un & $13 \mathrm{~V}$ & $15 k$ & TIF \\
\hline 15 & Thrust transients & Opt & $25 \%$ & 15/up & $\frac{1.0 \mathrm{r}_{\mathrm{s}}}{1.3 \mathrm{~V}_{\mathrm{s}}}$ & 10 to $15 \mathrm{k}$ & TLF \\
\hline 16 & Thrust transients & Opt & $25 \%$ & $35 / \mathrm{dn}$ & $1.3 \mathrm{~V}_{\mathrm{s}}$ & 10 to $15 \mathrm{k}$ & TLF \\
\hline 17 & Maneuvering char & Opt & $25 \%$ & $0 /$ up & $1.3 \mathrm{~V}_{\mathrm{s}}$ & 10 to $15 \mathrm{k}$ & TLF \\
\hline 18 & Maneuvering char & Opt & $25 \%$ & 0/up & $1.5 \mathrm{~V}_{\mathrm{s}}$ & 10 to $15 \mathrm{k}$ & TLF \\
\hline 19 & Maneuvering char & Opt & $25 \%$ & 0/up & $1.7 \mathrm{~V}_{\mathrm{s}}$ & 10 to $15 \mathrm{k}$ & TLF \\
\hline 20 & Maneuvering char & Opt & $25 \%$ & 0/up & 225 & 10 to $15 \mathrm{k}$ & TLF \\
\hline 21 & Maneuvering char & Opt & $25 \%$ & 0/up & 250 & 10 to $15 \mathrm{k}$ & TLF \\
\hline 22 & Pitch, roll, yaw doublets & Opt & $25 \%$ & 0/up & $1.3 \mathrm{~V}_{\mathrm{s}}$ & 10 to $15 \mathrm{k}$ & TLF \\
\hline 23 & Pitch, roll, yaw doublets & Opt & $25 \%$ & 0/up & $1.5 \mathrm{~V}_{\mathrm{s}}$ & 10 to $15 \mathrm{k}$ & TLF \\
\hline 24 & Pitch, roll, yaw doublets & Opt & $25 \%$ & 0/up & $1.7 \mathrm{~V}_{\mathrm{s}}$ & 10 to $15 \mathrm{k}$ & TLF \\
\hline 25 & Pitch, roll, yaw doublets & Opt & $25 \%$ & 15/up & $1.3 \mathrm{~V}_{\mathrm{s}}$ & 10 to $15 \mathrm{k}$ & TLF \\
\hline 26 & Pitch, roll, yaw doublets & Opt & $25 \%$ & 15/up & $1.5 \mathrm{~V}_{\mathrm{s}}$ & 10 to $15 \mathrm{k}$ & TLF \\
\hline 27 & Pitch, roll, yaw doublets & Opt & $25 \%$ & 15/up & $\mathrm{V}_{\mathrm{FE}}$ & 10 to $15 \mathrm{k}$ & TLF \\
\hline 28 & Pitch, roll, yaw doublets & Opt & $25 \%$ & 35/dn & $1.3 \mathrm{~V}_{\mathrm{S}}$ & 10 to $15 \mathrm{k}$ & TLF \\
\hline 29 & Pitch, roll, yaw doublets & Opt & $25 \%$ & $35 / \mathrm{dn}$ & $1.5 \mathrm{~V}_{\mathrm{s}}$ & 10 to $15 \mathrm{k}$ & TLF \\
\hline 30 & Pitch, roll, yaw doublets & Opt & $25 \%$ & $35 / \mathrm{dn}$ & $\mathrm{V}_{\mathrm{FE}}$ & 10 to $15 \mathrm{k}$ & TLF \\
\hline 31 & SHSS & Opt & $25 \%$ & 0/up & $1.3 \mathrm{~V}_{\mathrm{s}}$ & 10 to $15 \mathrm{k}$ & TLF \\
\hline 32 & SHSS & Opt & $25 \%$ & 0/up & $1.5 \mathrm{~V}_{\mathrm{s}}$ & 10 to $15 \mathrm{k}$ & TLF \\
\hline 33 & SHSS & Opt & $25 \%$ & 0/up & $1.7 \mathrm{~V}_{\mathrm{s}}$ & 10 to $15 \mathrm{k}$ & TLF \\
\hline 34 & SHSS & Opt & $25 \%$ & 15/up & $1.3 \mathrm{~V}_{\mathrm{s}}$ & 10 to $15 \mathrm{k}$ & TLF \\
\hline 35 & SHSS & Opt & $25 \%$ & 15/up & $1.5 \mathrm{~V}_{\mathrm{S}}$ & 10 to $15 \mathrm{k}$ & TLF \\
\hline 36 & SHSS & Opt & $25 \%$ & 15/up & $\mathrm{V}_{\mathrm{FE}}$ & 10 to $15 \mathrm{k}$ & TLF \\
\hline 37 & SHSS & Opt & $25 \%$ & $35 / \mathrm{dn}$ & $1.3 \mathrm{~V}_{\mathrm{s}}$ & 10 to $15 \mathrm{k}$ & TLF \\
\hline 38 & SHSS & Opt & $25 \%$ & $35 / \mathrm{dn}$ & $1.5 \mathrm{~V}_{\mathrm{S}}$ & 10 to $15 \mathrm{k}$ & TLF \\
\hline 39 & SHSS & Opt & $25 \%$ & $35 / \mathrm{dn}$ & $\mathrm{V}_{\mathrm{FE}}$ & 10 to $15 \mathrm{k}$ & TLF \\
\hline 40 & Stall characteristics & Opt & $25 \%$ & 0/up & $1.3 \mathrm{~V}_{\mathrm{s}}$ & 10 to $15 \mathrm{k}$ & Idle \\
\hline 41 & Stall characteristics & Opt & $25 \%$ & 15/up & $1.3 \mathrm{~V}_{\mathrm{s}}$ & 10 to $15 \mathrm{k}$ & Idle \\
\hline 42 & Stall characteristics & Opt & $25 \%$ & $35 / \mathrm{dn}$ & $1.3 \mathrm{~V}_{\mathrm{s}}$ & 10 to $15 \mathrm{k}$ & Idle \\
\hline
\end{tabular}




\section{References}

1. Gingras, D.R, Dickes, E.G, Ratvasky, T.P., and Barnhart, B.P, "Modeling of In-Flight Icing Effects for Pilot Training," AIAA Modeling and Simulation Technologies Conference and Exhibit, Aug. 5-8, 2002, Monterey, CA, AIAA Paper 2002-4605.

2. Ratvasky, T.P, Ranaudo, R.J., Barnhart, B.P., Dickes, E.G, and Gingras, D.R, "Development and Utility of a Piloted Flight Simulator for Icing Effects Training,” AIAA 41st Aerospace Sciences Meeting and Exhibit, Jan. 6-9, 2003, Reno, NV, AIAA Paper 2003-0022, NASA/TM-2003212116.

3. Papadakis, M., Gile Laflin, B.E., Youssef, G.M, and Ratvasky, T.P., “Aerodynamic Scaling Experiments with Simulated Ice Accretions,” AIAA 39th Aerospace Sciences Meeting and Exhibits, Jan. 8-11, 2001, Reno, NV, AIAA Paper 2001-0833.

4. Lee, S., Ratvasky, T.P., Thacker, M., and Barnhart, B.P., "Geometry and Reynolds Number on an Iced Business Jet Wing,” AIAA 43rd Aerospace Sciences Meeting and Exhibits, Jan. 10-13, 2005, Reno, NV, AIAA Paper 2005-1066.

5. Lee, S., Barnhart, B., Ratvasky, T.P., and Thacker, M., "Dynamic Wind-Tunnel Testing of a SubScale Iced Business Jet,” AIAA 44th Aerospace Sciences Meeting and Exhibits, Jan. 9-12, 2006, Reno, NV, AIAA Paper 2006-0261.

6. “Aircraft Ice Protection,” Advisory Circular AC No: 20-73A, 8/16/2006.

7. Ratvasky, T.P., Ranaudo, R.J., Blankenship, K.S., Lee, S., "Demonstration of an Ice Contamination Effects Flight Training Device” AIAA 44th Aerospace Sciences Meeting and Exhibit, Jan. 9-12, 2006, Reno, NV, AIAA Paper 2006-0677, NASA/TM-2006-214233.

8. D-Six Simulation Environment, Software Package Version, Bihrle Applied Research, Inc., Hampton, VA, http://www.bihrle.com/site/products_d6.html 


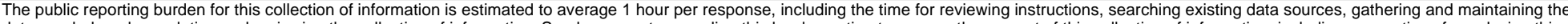

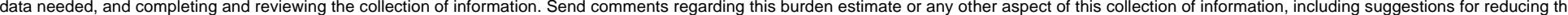

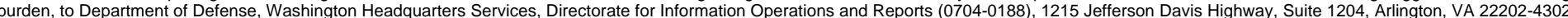

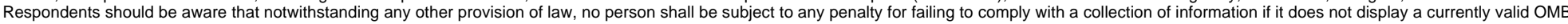
control number.

PLEASE DO NOT RETURN YOUR FORM TO THE ABOVE ADDRESS.

\section{REPORT DATE (DD-MM-YYYY) \\ 2. REPORT TYPE \\ 3. DATES COVERED (From - To)}

01-12-2007

\section{TITLE AND SUBTITLE}

Technical Memorandum

Flight Testing an Iced Business Jet for Flight Simulation Model Validation

5a. CONTRACT NUMBER

5b. GRANT NUMBER

5c. PROGRAM ELEMENT NUMBER

\section{AUTHOR(S)}

Ratvasky, Thomas, P.; Barnhart, Billy, P.; Lee, Sam; Cooper, Jon

5d. PROJECT NUMBER

5e. TASK NUMBER

5f. WORK UNIT NUMBER

WBS 457280.02.07.03.02

\section{PERFORMING ORGANIZATION NAME(S) AND ADDRESS(ES)}

National Aeronautics and Space Administration

\section{PERFORMING ORGANIZATION}

REPORT NUMBER

John H. Glenn Research Center at Lewis Field

E-16113

Cleveland, Ohio 44135-3191

\section{SPONSORING/MONITORING AGENCY NAME(S) AND ADDRESS(ES)}

National Aeronautics and Space Administration

Washington, DC 20546-0001

\begin{tabular}{|c|}
\hline $\begin{array}{l}\text { 10. SPONSORING/MONITORS } \\
\text { ACRONYM(S) } \\
\text { NASA }\end{array}$ \\
\hline $\begin{array}{l}\text { 11. SPONSORING/MONITORING } \\
\text { REPORT NUMBER } \\
\text { NASA/TM-2007-214936; AIAA-2007- } \\
0089\end{array}$ \\
\hline
\end{tabular}

\section{DISTRIBUTIONIAVAILABILITY STATEMENT}

Unclassified-Unlimited

Subject Categories: 05 and 08

Available electronically at http://gltrs.grc.nasa.gov

This publication is available from the NASA Center for AeroSpace Information, 301-621-0390

\section{SUPPLEMENTARY NOTES}

\section{ABSTRACT}

A flight test of a business jet aircraft with various ice accretions was performed to obtain data to validate flight simulation models developed through wind tunnel tests. Three types of ice accretions were tested: pre-activation roughness, runback shapes that form downstream of the thermal wing ice protection system, and a wing ice protection system failure shape. The high fidelity flight simulation models of this business jet aircraft were validated using a software tool called "Overdrive.” Through comparisons of flight-extracted aerodynamic forces and moments to simulation-predicted forces and moments, the simulation models were successfully validated. Only minor adjustments in the simulation database were required to obtain adequate match, signifying the process used to develop the simulation models was successful. The simulation models were implemented in the NASA Ice Contamination Effects Flight Training Device (ICEFTD) to enable company pilots to evaluate flight characteristics of the simulation models. By and large, the pilots confirmed good similarities in the flight characteristics when compared to the real airplane. However, pilots noted pitch up tendencies at stall with the flaps extended that were not representative of the airplane and identified some differences in pilot forces. The elevator hinge moment model and implementation of the control forces on the ICEFTD were identified as a driver in the pitch ups and control force issues, and will be an area for future work.

\section{SUBJECT TERMS}

Aircraft icing; Flight simulaton; Flight simulators; Flight safety

\begin{tabular}{|c|c|c|c|}
\hline 16. SECURIT & ASSIFICATION & & 17. LIMITATION OF \\
\hline $\begin{array}{l}\text { a. REPORT } \\
\mathrm{U}\end{array}$ & $\begin{array}{l}\text { b. ABSTRACT } \\
U\end{array}$ & $\begin{array}{l}\text { c. THIS } \\
\text { PAGE } \\
\text { U }\end{array}$ & UU \\
\hline
\end{tabular}

18. NUMBER
OF
PAGES
22

19a. NAME OF RESPONSIBLE PERSON
STI Help Desk (email:help@sti.nasa.gov)
19b. TELEPHONE NUMBER (include area code)
301-621-0390



